This is a post-refereeing accepted version. Please refer to the published version when citing:

Hall, C.M., Amelung, B., Cohen, S., Eijgelaar, E., Gössling, S., Higham, J., Leemans, R., Peeters, P., Ram, Y. \& Scott, D. (2015). On climate change skepticism and denial in tourism. Journal of Sustainable Tourism, 23(1), 4-25.

\title{
On climate change skepticism and denial in tourism
}

\begin{abstract}
The period leading to and immediately after the release of the IPCC's fifth series of climate change assessments saw substantial efforts by climate change denial interests to portray anthropogenic climate change (ACC) as either unproven theory or a negligible contribution to natural climate variability, including the relationship between tourism and climate change. This paper responds to those claims by stressing that the extent of scientific consensus suggests that human-induced warming of the climate system is unequivocal. Secondly, it responds in the context of tourism research and ACC, highlighting tourism's significant contribution to greenhouse gas emissions, as well as climate change's potential impacts on tourism at different scales. The paper exposes the tactics used in ACC denial papers to question climate change science by referring to non-peer reviewed literature, outlier studies and misinterpretation of research, as well as potential links to think-tanks and interest groups. The paper concludes that climate change science does need to improve its communication strategies but that the world-view of some individuals and interests likely precludes acceptance. The connection between ACC and sustainability illustrates the need for debate on adaptation and mitigation strategies, but that debate needs to be grounded in scientific principles not unsupported skepticism.
\end{abstract}

Keywords: climate change denial; Intergovernmental Panel on Climate Change (IPCC); climate change consensus; climate models; climate change mitigation; greenhouse gas emissions 
Introduction

Climate, as well as the natural environment, has always been changing. What is now different is that human influence on natural systems is so extensive that geologists now refer to our contemporary period as the Anthropocene' (Oldfield \& Steffen, 2014). Climate change is extremely significant for tourism because of its influences on the economic viability of tourist destinations and activities, tourist behavior, and its ramifications for the entire tourism system. This is a situation well recognised both by industry and policy makers (e.g. UNWTO-UNEP-WMO, 2008), and the academic community (see Becken and Hay (2012) and Scott, Hall and Gössling (2012) for overviews).

In the scientific community anthropogenic climate change is now accepted (Anderegg, Prall, Harold \& Schneider, 2010; Cook et al., 2013, 2014a, 2014b; Doran \& Zimmerman, 2009; Maibach, Myers \& Leiserowitz, 2014; Oreskes, 2004). Over a decade ago, a joint statement by 17 national science academies (2001) concluded: "The work of the Intergovernmental Panel on Climate Change (IPCC) represents the consensus of the international scientific community on climate change science. We recognise IPCC as the world's most reliable source of information on climate change and its causes, and we endorse its method of achieving this consensus" (Science, 2001, p.1261). It should also be stressed that 195 countries endorse the IPCC summary for policy maker documents before they are released. It is not "a highly controversial scientific topic" (Shani \& Arad, 2014a, p.82). Instead, what is controversial, and is extremely important in the wider tourism context, is the extent to which it is a topic of public debate in which scientific findings and reasoning have become obfuscated by vested interests and a few outlier studies of climate change, often from nonrefereed sources, in an attempt to influence government, private sector and citizen action (Dunlap, 2013; Friel, 2010; Gelbspan, 1997; Hall et al., 2014a, 2014b; Hoggan, 2009; Hulme, 2009; Manne, 2012; Oreskes \& Conway, 2010).

The acceptance of two papers in Tourism Management on it being a time for "environmental skepticism" (Shani \& Arad, 2014a) and "rational skepticism" (Shani \& Arad, 2014b) on the tourism and climate change relationship is not a 'head in the sand' approach to climate change and sustainable tourism. It is actually far worse. To claim that references used by tourism scholars engaged in climate change research "ignore the critical debate on the accurateness and implications of the theory of anthropogenic global warming (AGW), which in actual fact is far from being conclusive" (Shani \& Arad, 2014a, p.82), that "the theory of AGW is, in fact, under intense scientific dispute" (Shani \& Arad, 2014a, p 83), and that "the theory of AGW is highly controversial among climate scientists" (Shani \& Arad, 2014a, p.84) is to deliberately misrepresent both contemporary scientific accounts of climate change as well as the extensive dialogue within the tourism academy with respect to climate change and its interrelationships with tourism and sustainability (Hall et al., 2014a, 2014b; see also Gössling, Hall, Lane \& Weaver, 2008; Scott, 2011; Weaver, 2011). In fact, such comments reflect what Mann (2012, p.60) describes as "the Potemkin village of climate change denial", settled by organizations such as the Cato and Heartland Institutes. ${ }^{\text {ii }}$ That Shani and Arad (2014a, 2014b) utilise such sources to present their own 'skeptical' account of "climate change hype" (Shani \& Arad 2014a, p.83), and tourism, is unsurprising given their institutional linkage to the Ayn Rand Institute which has supported climate change denier conferences (Hoffman, 2011) and whose web site includes several presentations that provide 'critiques' of climate change science and policy (e.g. Lockitch 2009a, 2009b). 
Moreover, the conclusion by Shani and Arad (2014b) that

"wealthier is healthier," since as societies become more affluent their capacity to adapt to changing environmental conditions is significantly improved. Consequently, effectively preparing our students for managerial positions in the tourism industry and focusing our research on the commercial aspects of tourism are probably the tourism academy's functions with the most sustainable outcomes

raises broader questions about the nature of the sustainability debate in tourism, especially with respect to the extent that it is realistically possible to have economic and tourism growth and not lead to a decline in natural capital. There is no simple and predictable relationship between the environment and per capita income per se so that as incomes or GDP rise environmental impacts decline (the so-called environmental Kuznets curve) (Dietz \& Adger, 2003; Stern, 2004, 2014; Mozumder, Berrens \& Bohara, 2006; Czech, 2008; Mills \& Waite, 2009; Kijima, Nishide \& Ohyama, 2010). Although it is often not stated, such concerns lie at the heart of the way in which notions of sustainable tourism are framed and contested because they suggest that the priority should be to grow first then clean up later (Dasgupta, Laplante, Wang \& Wheeler, 2002), i.e. that the focus should be on only a slightly modified Business As Usual (BAU) approach, rather than paradigm change (Hall, 2011). These concerns also challenge 'short-term' or 'stop-gap' measures. Moreover, it also highlights the importance of the framing of sustainability and climate change debates with respect to what is included and what is left out. For example, early in the debate over the environmental Kuznets curve, Torras and Boyce (1998) highlighted that a more equitable distribution of power contributes to the lowering of pollution levels, by enhancing the influence on policy of those who bear the costs of pollution, relative to the influence of those who benefit from pollution-generating activities with literacy, political rights, and civil liberties found to have particularly strong effects on environmental quality. Such observations reinforce that sustainable development as originally conceived by the WCED (1987), was not just about economic growth, employment and the environment but was also concerned with equity.

This paper responds to the numerous spurious claims made by Shani and Arad (2014a, b) with respect to the realities of climate change, research on the current and potential effects of climate change and tourism, and how the tourism industry and destinations should react. Although Hall et al. (2014a, 2014b) provided a specific response to Shani and Arad (2014a, b) this paper seeks to provide a broader critique, given that Shani and Arad's claims and methods of argument are representative of a broader approach to climate change denial and dogmatism (Wilson, 2008). We emphasise that knowledge claims with respect to climate change need to be supported by peer-reviewed evidence. We also question the suggestion by Shani and Arad that there is a failure by tourism researchers to debate climate change science and theory. As will be noted, consensus does not imply unanimity. There is considered deliberation on how climate change issues should be framed, both within the wider scientific community (e.g. Demeritt 2001a, 2001b, 2006; Demeritt \& Rothman, 1999; Esbjörn-Hargens, 2010; Hulme, 2011; O’Brien, 2011; Schneider, 2001; Turnpenny, Jones \& Lorenzoni, 2011), as well as in the particular community of scholars who work on tourism and climate change (e.g. Bigano, Hamilton, Maddison \& Tol, 2006; Gössling \& Hall 2006a, 2006b; Scott, 2011; Scott, Hall \& Gössling, 2012; Weaver, 2011). Indeed, in his critique of scientific knowledge of climate change modelling and its validation, Demeritt's (2001a) criticisms sought "to refute neither the existence of global warming nor of socially contingent knowledge of it" (2001a, p.327), but instead to improve the quality of climate 
change knowledge and its communication by rigorous examination of its assumptions, construction, and politics. It is in that same spirit that our own response is made.

This commentary is divided into three main sections. First, we respond to the specific issues raised by Shani and Arad (2014a, 2014b) in relation to the science of climate change.

Second, we respond to the questions they raised with respect to tourism and climate change relationships. Finally, we conclude with some observations on the consensus on climate change and its implications for debate and action. We would note that we will tend throughout the paper to use the term climate change as opposed to AGW given that increases in globally averaged atmospheric and ocean temperatures should be understood as part of the broader climate system and, hence, global climate change. Other dimensions of both the climate system (e.g. cryosphere, hydrosphere, geomorphology (land surface), and biosphere), and aspects of climate change (e.g. ocean acidification, $\mathrm{CO}_{2}$ fertilisation, and frequency of extreme events), are also vitally important for the functioning and stability of the global ecosystem, on which humans depend (IPCC, 2013a).

\section{The science of climate change: human-induced warming of the climate system is unequivocal}

According to Shani and Arad "most apocalyptic predictions regarding AGW are based on simulations of the IPCC's computer climate models, which so far have not demonstrated a high level of accuracy" (2014a, p.83). Anthropogenic climate change, however, is not only about the future, it has already begun (IPCC, 2013a). As a result, the evidence for warming is not just based on 'predictions' but on observations. Next to more recent satellite observations, these include global instrumental observations since the nineteenth century, paleo-climate reconstructions and responses of environmental and ecosystem changes on all continents and oceans (IPCC 2013a, 2014a). These combined observations provide extremely strong evidence for atmospheric and ocean warming. The climate models, which are not IPCC models - (they have been developed by academic and government research teams from many countries) - have improved considerably since they were first developed and are well validated, a point about which we will return to below. The IPCC does not perform research on its own. Its reports are syntheses of scientific research funded by hundreds of different sources and undertaken by thousands of scientists. A key conclusion of the IPCC (2013b) then is that "Warming of the climate system is unequivocal, and since the 1950s, many of the observed changes are unprecedented over decades to millennia [see also reports by World Meteorological Organization, 2013]. The atmosphere and ocean have warmed, the amounts of snow and ice have diminished, sea level has risen, and the concentrations of greenhouse gases have increased" (IPCC, 2013b, p.2). Nevertheless, the IPCC does not assume that "the planet is warming at a (...) destructive rate" as Shani and Arad (2014a) write. The word destructive is not used in the IPCC's (2013a) Assessment Report from Working Group 1 (AR5 WGI) on the science of climate change. Yet, as serious as the IPCC conclusions are, it is important to stress that IPCC projections are not apocalyptic. Instead, available evidence suggests that as a result of scientific norms of dispassion, restraint, skepticism, rationality, and moderation, as well as peer-review that involves a wide range of organizations and institutions, they represent conservative interpretations of climate change and err on the side of less rather than more alarming predictions (Brysse, Oreskes, O’Reilly, \& Oppenheimer, 2013). 
With respect to reasons for contemporary atmospheric and oceanic warming, the full range of natural (e.g., solar, volcanic) and anthropogenic (e.g., GHG and aerosol emissions, land use change) drivers have been considered by scholars and the IPCC. Combining models and observations has been instrumental in assessing the relative contribution of each of the potential climate forcing mechanisms. While solar and volcanic activity influence the climate, they cannot explain the warming trend that has been observed over the last 40 years. Human influence, including anthropogenic GHG emissions, has been the dominant force in global warming. It is extremely likely (>95\% level of certainty) "that human influence has been the dominant cause of the observed warming since the mid-20th century" (IPCC, $2013 b$, p.15). Furthermore, "It is extremely likely that more than half of the observed increase in global average surface temperature from 1951 to 2010 was caused by the anthropogenic increase in greenhouse gas concentrations and other anthropogenic forcings together" (IPCC, 2013b, p.15).

Models taking all known influences into account have become very successful at accurately reproducing observed temperature changes. Climate models reproduce observed large-scale mean surface temperature patterns very well (pattern correlation of 0.99) (IPCC, 2013a, p.743) and their performance continues to improve. The IPCC shows "very high confidence" that "models reproduce observed continental- scale surface temperature patterns and trends over many decades, including the more rapid warming since the mid-20th century and the cooling immediately following large volcanic eruptions" (IPCC, 2013b, p.13). Model accuracy has also improved for regional scales, but continues to be lower than for the global scale, something which the IPCC (2013a, p.743) clearly acknowledges. Similarly, model performance for large-scale precipitation patterns continues to be lower than for surface temperature patterns because of the spatial resolution of global climate models relative to some important precipitation processes (e.g., convective storms) (IPCC, 2013a). Climate models do not reproduce single events but rather they produce statistical properties describing the climate. Indeed, we would stress that validation of any future oriented model is inherently imperfect given that by definition there is no data completely reflecting future conditions as they are, by definition, unknown. Nevertheless, model test schemes are continually being improved in relation to their application for projections by use of single models, ensemble modeling and space-time-substitution and in relation to use of different data from historical time series, paleo-data and controlled experiments for specific purposes (Refsgard et al., 2014; Gleckler, Taylor \& Doutriaux, 2008).

Shani and Arad also suggest "while actual global temperatures have remained fairly stable over the past 17 years, the IPCC's models predicted a significant rise in temperature" (2014a, p.83). It is true that global surface temperatures have risen more slowly in the period 19982012 than in the period 1951-2012. This slow-down has, with medium confidence, been attributed in roughly equal measure to two main causes: 1 ) a reduced trend in external forcing, and 2) natural internal variability. External forcing is lower because of a downward phase in the solar cycle, which is well understood, combined with less volcanic activity, the role of which is less certain, due to interference with the uncertain aerosol forcing trend (IPCC, 2013a; see also Schmidt, Shindell \& Tsigaridis, 2014).

Natural internal variability explains most of the difference between the recent observed decrease in the warming trend and modeled surface temperature increases. Natural internal variability includes the redistribution of heat between the atmosphere, cryosphere (ice) and oceans. More than $90 \%$ of the net energy increase in the climate system is stored in the 
oceans (IPCC, 2013b, p.8), whereas only a small percentage is stored in the atmosphere. As a result, even small fluctuations in the energy distribution between oceans, ice and air may cause substantial variations in the warming trend of surface temperatures. A pronounced strengthening in Pacific trade winds over the past two decades, a trend unprecedented in observations and not captured by current global climate models, is a mechanism that has increased transfer of heat to ocean depths and can account for a slowdown in surface warming in the Pacific (England et al., 2014).

Climate models are expected to capture the trends in the climate system, not its internal variability. Regardless of the slower increase of global mean surface temperature, it is very likely that the climate system as a whole, i.e. including the ocean, has continued to accumulate heat (IPCC, 2013a). The observation that the atmosphere has been heating up relatively slowly implies that other parts of the climate system have been warming up more quickly than before. It is highly likely that the oceans have accumulated further energy. One clear indication is that "global mean sea level has continued to rise during 1998-2012, at a rate only slightly and insignificantly lower than during 1993-2012" (IPCC, 2013a, p.769). In addition, it is important to note that even though global mean surface temperature has not risen as rapidly as before, it has still been increasing. As a matter of fact, the decade of the 2000s has been the warmest in the instrumental record (IPCC, 2013a, p.769). The slower increase of surface temperature is not comforting at all. Due to the same natural variability, the near future is likely to see a period of above-average increases in surface temperatures.

Shani and Arad go on to suggest, "It seems far too hasty and irresponsible to recommend that the tourism industry take drastic and expensive courses of action that are based on climate forecasting models that have demonstrated very limited success" (2014a, p.83). The issue of recommendations for tourism industry action is discussed further below. But with respect to the success of climate forecasting models their performance in reproducing largescale mean surface temperature patterns has been robust (see above). The contribution of anthropogenic greenhouse gas emissions (GHG) to warming has been large, at least $50 \%$ since 1950 (IPCC, 2013a). As long as anthropogenic GHG emissions are not reduced sharply, atmospheric GHG concentrations will continue to increase, further pushing surface temperature up. In contrast to Shani and Arad's arguments, the IPCC (2014a) outlines that without serious mitigation, adaptation efforts will face limits, increasing the risk of major ecological, economic, and societal disruptions. In order to reduce the dangers of climate change, emissions will need to be reduced by all sectors with significant shares of emissions (IPCC, 2014b). Tourism is such a sector (Gössling, 2013; UNWTO-UNEP-WMO, 2008). The tourism industry has so far been lagging behind and is set on a course to double its emissions over the coming 25 years (Dubois, Peeters, Ceron \& Gössling, 2011; Gössling, Scott \& Hall, 2013; Scott, Peeters \& Gössling, 2010).

Selective reading of literature can be a major factor compounding understanding of climate change (Tol, 2008; Hall et al., 2014a, 2014b). Shani and Arad (2014a, p.83) claim that "recent studies reveal that there have been eras in which the earth's average temperature was higher than at present, even during recorded history." One of these studies (Marcott et al., 2013) shows that current temperatures have not yet exceeded the highest temperatures in the early Holocene, 5,000 to 10,000 years ago (well before recorded history), but notes that future temperatures are expected to soon exceed them. They also observe that in just one century, global temperatures have moved through almost the whole spectrum of Holocene temperatures, starting at the cool end and nearing the warm end at the moment: 
"Global temperature, therefore, has risen from near the coldest to the warmest levels of the Holocene within the past century, reversing the long-term cooling trend that began 5000 yr B.P. Climate models project that temperatures are likely to exceed the full distribution of Holocene warmth by 2100 for all versions of the temperature stack..., regardless of the greenhouse gas emission scenario considered (excluding the year 2000 constant composition scenario, which has already been exceeded)" (Marcott et al., 2013, p.1201).

Similarly, Shani and Arad suggest that Esper, Büntgen, Timonen, and Frank (2012) provide evidence "for substantial warmth during Roman and Medieval times, larger in extent and longer in duration than 20th century warmth (p.1)" (2014a, p.83). In reality, the Esper et al. (2012) study only discusses uncertainties in summer temperature reconstructions in Northern Scandinavia and does not refute the assertion that "the planet is in the midst of an unprecedented rise in temperatures" (Shani \& Asad, 2014a, p.83).

With respect to movements in global temperatures Shani and Arad (2014a, p.83) claim, "Further studies also confirm that major temperature fluctuations occurred before manmade $\mathrm{CO}_{2}$. If the IPCC's assessments are accurate and natural factors scarcely play any role in today's climate, we would expect a rather flat and uninteresting climate history, which is certainly not the case (Vahrenholt, 2012)." Vahrenholt (2012) is a commentary piece in The Telegraph newspaper, not a scientifically reviewed article. This statement is further misleading because in no way does the IPCC claim "that natural factors scarcely play any role in the climate." The IPCC (2013a, p.11) explicitly states, "Natural and anthropogenic substances and processes that alter the Earth's energy budget are drivers of climate change." What the IPCC (2013a) and scientific community have concluded is that natural processes alone cannot explain the contemporary changes to climate, including with respect to mean atmospheric and oceanic temperatures.

Shani and Arad (2014a, p.83) suggest "there are shaky scientific foundations to the hypothesis that $\mathrm{CO}_{2}$ concentration in the earth's atmosphere accounts for significant temperature fluctuations, empirical evidence indicates that the sun activity is a more plausible cause for climate variation" (as well as "natural factors" including "changes in the galactic environment"), and that "no definitive evidence exists to verify that climate is driven by the concentration of $\mathrm{CO}_{2}$ in the earth's atmosphere". This is supported by reference to a non-peer-reviewed document published by the Heartland Institute and selective citation of other sources that discuss natural processes that potentially affect climate in specific locations and times (e.g. Bond et al., 2001; Neff et al., 2001). Changes in the atmospheric abundance of greenhouse gases, including carbon dioxide, and aerosols, in solar radiation and in land surface properties alter the energy balance of the climate system and serve as drivers of climate change. Carbon dioxide is regarded as the most important GHG today and is the primary GHG emitted through human activities. It has long been recognized that $\mathrm{CO}_{2}$ is a major climate influence. For example, the first paper explaining why Venus is warmer than Earth and Earth is warmer than Mars was by Fourier (c. 1824) who explained this by the atmospheric compositions of these planets (and the distance to the Sun). The first paper on measuring radiative forcing by $\mathrm{CO}_{2}$ and other gases was by Tyndall (1849). This has been experimentally observed and explained many times and is nowadays a part of basic highschool physics curricula. Arrhennius (1896) used this foundational science to examine the 
temperature increase of $\mathrm{CO}_{2}$ doubling from human activities (coal burning at the time) (all these seminal papers are reprinted in Archer \& Pierrehumbert, 2011).

Similarly, Shani and Arad (2014a, p.83) argue "First and foremost, geologic analyses reveal ancient periods with thousands PPM (parts per million) of $\mathrm{CO}_{2}$ concentration, in comparison to 400 PPM at present (Petit et al., 1999)." This is either a failure to read Petit et al. correctly or deliberate misrepresentation. The Petit study is about reconstructing the climate going back 420,000 years using ice cores. In the entire study period, $\mathrm{CO}_{2}$ concentrations were never higher than now, let alone 'thousands ppm'. Petit et al. $(1999, \mathrm{p} .433)$ state: "The extension of the greenhouse-gas record shows that present-day levels of $\mathrm{CO}_{2}$ and $\mathrm{CH}_{4}$ (approx 360 p.p.m.v. [parts per million by volume] and approx 1,700 p.p.b.v., respectively) are unprecedented during the past 420 kyr [thousand years]." Atmospheric $\mathrm{CO}_{2}$ concentrations are of course known to have varied substantially during the evolution of the Earths' atmosphere. These variations are linked to changing climatic conditions. For example, it is higher concentrations of greenhouse gases that explain how surface temperatures were not well below freezing when the sun's luminosity was substantially less then today (the 'faint young sun paradox' (Rosing et al., 2010)). More recently, the decline in atmospheric $\mathrm{CO}_{2} 34$ million years ago was the primary agent forcing Antarctic glaciation (Pagani et al., 2011). References to atmospheric conditions tens or hundreds of millions of years ago are a distraction. Climate scientists concentrate on near-term ( $<1$ million years) climate fluctuations, those typical of recent glacial-interglacial periods, to understand what elevated greenhouse gases and other changes in forcing mechanism might mean for our future climate.

In a seemingly increasingly desperate attempt to find something to attack in the "theory of anthropogenic global warming," Shani and Arad (2014a, p.83) state

"A recent study provides evidence to suggest that El Niño activity has a major role in the warming observed since the 1970s, and thus the climate system is much less sensitive to increasing $\mathrm{CO}_{2}$ than commonly believed (Spencer \& Braswell [2014]). Another plausible explanation for the current warming 'pause' was provided by Wyatt and Curry [2013], who attributed the hiatus to the natural "stadium wave" signal that propagates across the Northern Hemisphere."

First of all, the tactic of referring continually to AGW as a "theory" is reminiscent of the sort of extra-scientific fundamentalism that evolutionary science encounters - if something is described as a theory often enough (it is used nine times in Shani and Arad's (2014a) and four times in 2014b) then maybe people will think that the science is unsupported and therefore questionable (see Mervis, 2006).

Reference to outlier studies is another tactic used by those that deny the existence of anthropogenic climate change (Manne, 2012). The existence of outlier results, studies and interpretations is not by itself a negative, as they may potentially shed light onto a research problem (e.g. Barnett, 2004). However, it is fundamental to scientific argumentation that if you are referring to an outlier then it should be rigorously checked as well as being relevant to the argument that is being made. For example, in citing Spencer and Braswell (2014) Shani and Arad (2014a, b) did not contextualise it by noting that this is only one of numerous models of the El Niño - Southern Oscillation (ENSO) nor note that the issues associated with modeling the variations of the amplitude and spatial patterns of ENSO and matching existing 
data are well recognised (e.g. Collins et al., 2010; IPCC, 2013a). For example, in the previous issue to Spencer and Braswell's (2014) paper, Yeh, Kug and An (2014) argued that two different types of ENSO exist (Cold Tongue [CT] and Warm Pool [WP] El Niño), with increased greenhouse forcing leading to a change in the dominance of El Niño with the WP EI Niño becoming more prominent. According to Yeh et al. (2014) predictions remain challenging because the natural modulation range of ENSO may be close to, or more than, the range of ENSO changes induced by $21^{\text {st }}$ century climate forcing concluding "the overall future prospect on which type of El Niño will occur more frequently is rather uncertain, but the intensification of WP EI Niño as observed in several objectively selected models remains a possible answer on how the type of El Niño will be in a future" (Yeh et al., 2014, p.76).

The findings of Wyatt and Curry (2013) (the latter is also a critic of the IPCC process with respect to climate uncertainty: see Committee of Science and Technology, 2010; Curry, 2011), proposed that a 'stadium wave' climate signal is propagated across the Northern Hemisphere through a network of ocean, ice, and atmospheric circulation regimes that selforganize into a collective tempo and which describes the behaviors of large-scale circulation regimes in the atmosphere and ocean (e.g. El Niño/La Niña; Atlantic Multidecadal Oscillation [AMO]; Pacific Decadal Oscillation) in a spatially and temporally ordered manner. Wyatt and Curry's (2013) findings are refuted by Mann, Steinman and Miller (2014), who found that the true AMO signal appears likely to have been in a cooling phase in recent decades, offsetting some anthropogenic warming and explaining some of the observed slowing of warming during that timeframe. They conclude that there is no inconsistency between recent observed and modeled temperature trends. With specific reference to the Wyatt and Curry (2013) paper they state "Claims of multi-decadal 'stadium wave' patterns of variation across multiple climate indices are also shown to likely be an artifact of [their] flawed procedure for isolating putative climate oscillations" (Mann et al., 2014).

In examining climate change science Shani and Arad (2014a, b) demonstrate a significant failure to compare and contrast different interpretations, methods and approaches to specific debates in the climate change literature (Hall et al. 2014a, 2014b). Indeed, it is remarkable that with respect to their discussion of climate model performance and the 'hiatus' in global-mean surface warming of the past 15 years (in which the observed globalmean surface temperature (GMST) has shown a much smaller increasing linear trend over the past 15 years than over the past 30 to 60 years), that they neither cited the extensive IPCC (2013a) discussion, nor a number of the numerous recent authoritative other papers on the subject (see Nature Geoscience (2014) for an excellent summary of the issue and links to relevant papers; see also Balmaseda, Trenberth \& Källén, 2013; Trenberth \& Fasullo, 2013). Nevertheless, it is important to stress, and as also noted in the introduction to this paper, "the average rate of warming at the Earth's surface is only one piece in the climate change puzzle" (Nature Geoscience, 2014, p.157). This is not to suggest that understanding such processes are unimportant. Far from it. Instead it means that climate change research needs to be grounded in the extensive literature dedicated to understanding complex systems rather than selective interpretations of isolated papers or op-eds ${ }^{\mathrm{iii}}$ in newspapers. As the Nature Geoscience editorial concluded,

... in the course of this pursuit we must not lose sight of the more complicated expressions of climate change - for example, on continental or smaller spatial scales, in variables other than surface temperature, and in terms of extremes around the 
average. These changes are less easy to summarize, but they have the potential to affect life on the planet much more severely (Nature Geoscience, 2014, p.157).

Indeed, it is indicative of a failure to reflect the expressions of climate change that the final substantive claim of Shani and Arad with respect to skepticism over human induced climate change was "Tol (2013) reviewed 14 different studies on the effects of future climate trends and discovered a scientific consensus that the benefits of global warming outweigh the costs, and its positive effects are likely to continue through about 2080" (Shani \& Arad, 2014a, pp.83-84). Such claims have already been refuted by the IPCC (2014a) that emphasized the risks posed by climate change especially with respect to food, water and human security. Indeed, Tol (2013) suggests that climate change may have been beneficial in the $20^{\text {th }}$ century, but not anymore in the $21^{\text {st }}$ century: "Most rich and most poor countries benefitted from climate change until 1980, but after that the trend is negative for poor countries and positive for rich countries. In the 21st century, impacts turn negative in most countries, rich and poor. Future climate change is a reason for concern" (Tol, 2013, p.127).

\section{Tourism, tourism research and climate change}

There is a substantial, and increasing, amount of research on tourism and climate change as evidenced by a number of reviews of the area (e.g. Becken \& Hay, 2012; Kaján \& Saarinen, 2013; Scott, 2011; Scott, Gössling \& Hall, 2012; Scott et al., 2012; Scott \& Matthews, 2011; UNWTO-UNEP-WMO, 2008). Nevertheless, Shani and Arad (2014a, p.84) assert, "While tourism scholars are not expected to be climate scientists, those who study climate change and tourism should exercise extra caution and adopt a critical approach when evaluating the subject matter." This can be responded to at a number of different levels (see also Hall et al. 2014a). First, unlike Shani and Arad, a number of people involved in the climate change and tourism research area do have a background in physical science, including some of the authors of this paper. However, one of the most important aspects of climate change is that it is an interdisciplinary area requiring contributions from both natural and social scientists, especially as climate change research is based on past, current and future oriented research (Ford et al., 2012; Ford, Knight \& Pearce, 2013; Murphy, 2011). Indeed, such an approach is essential not just for purposes of problem definition and solution, but also to improve the communication of climate change science and the degree of agreement and confidence in climate change research, including the work of the IPCC and other international bodies (Bracken \& Oughton, 2006; Weichselgartner \& Kasperson, 2010; Winowiecki et al., 2011). Second, to suggest that tourism researchers in the climate change area do not exert sufficient caution, or are not critical enough in examining the subject matter, demonstrates a substantial lack of awareness and knowledge of the tourism literature on the subject and the rigorous debate that occurs. There are different ways of framing climate change and the best means to respond. Such debates with respect to climate change need to be encouraged. What the majority of tourism scholars do not do, unlike Shani and Arad, is to seek to refute the existence of anthropogenic climate change or claim that its effects are so miniscule that the approach should be to do nothing or that "focusing [the tourism academy's] research on the commercial aspects of tourism" will lead to "the most sustainable outcome" (Shani and Arad, 2014b).

Shani and Arad (2014a) also laid out three, and in part 'loaded', questions with respect to tourism and climate change. These will now be answered in turn by focusing on the scientific judgments with respect to the reality of the phenomena of climate change 
Is climate change an ongoing cataclysm that requires society to take pressing and radical steps, even at the expense of social and economic progress? (Shani \& Arad, 2014a, p.82)

The notion of 'progress' is used by Shani and Arad (2014a) in an almost pejorative fashion, and can be used to describe almost anything. Scientific evidence provides sufficient certainty that climate change is real and that anthropogenic GHG emissions need to be substantially reduced together with other steps to reduce the negative effects of global environmental change. There is clearly disagreement over the timing and nature of interventions, including the appropriate balance between voluntary, market-based and regulatory measures. However, the UN Framework Convention on Climate Change (Article 3), which virtually every country is a signatory of, stipulates that the precautionary principle needs to be applied to anticipate, prevent or minimize the causes of climate change and mitigate its adverse effects. Whether suggestions that interventions should be applied sooner rather than later in order to enable appropriate economic transitions (Gössling, Hall, Ekström, Brudvik Engeset, \& Aall, 2012; IPCC, 2014b) are "radical" or not depends on personal political standpoints, but there has been substantial emphasis placed on the potential economic benefits for such an approach via such concepts as the green economy and green growth. Urgency in the implementation of climate change mitigation and adaption measures may then minimize the harmful impact on ecosystems and biodiversity that provide the environmental services on which personal and economic well-being depends (Millennium Assessment, 2005). As it currently stands most measures of "net" social and economic growth do not take into account the actual loss of valuable ecosystem services that for now we are getting for 'free' from the environment, nor is there a debate as to for whose benefit or expense "social and economic progress" would be. As a majority of humanity continues to be dependent on the immediate services provided by ecosystems, it would appear prudent not to jeopardize these ecosystems' functioning and capacity (Guo, Zhang \& Li, 2010). We, therefore, argue that in responding to climate and environmental change the focus should be on development, which is a measure of quality, rather than growth, which is a measure of quantitative change (Hall, 2009, 2010). With regard to the notion of economic costs involved in addressing climate change, there is strong evidence that the global tourism system is highly wasteful of resources and that even considerable mitigation efforts would have no overall negative economic impact (Gössling 2010).

Is the global tourism industry a significant contributor to destructive climate change and does it therefore have a moral obligation to considerably diminish its greenhouse gas footprint and educate tourists to alter their travel behavior? (Shani \& Arad, 2014a, p.82)

Tourism is a significant contributor to climate change. Tourism and travel contribute to climate change through emissions of GHGs, including $\mathrm{CO}_{2}$, methane $\left(\mathrm{CH}_{4}\right)$, nitrous oxides (NOx), hydrofluorocarbons (HFCs), perfluorocarbons (PFCs), and sulfur hexafluoride ( $\left.\mathrm{SF}_{6}\right)$. There are also various short-lived GHGs that are important in the context of aviation and, to a lesser extent, cruise ships (Scott, Hall \& Gössling, 2012). There is also a further, though unquantified, contribution to climate change as a result of tourism related land use changes.

Tourism transport, accommodation, and activities are estimated by two independent analyses to have contributed approximately $5 \%$ to global anthropogenic emissions of $\mathrm{CO}_{2}$ in the year 2005 (UNWTO-UNEP-WMO, 2008; World Economic Forum [WEF], 2009; Scott, Peeters \& Gössling, 2010). The majority of $\mathrm{CO}_{2}$ emissions are associated with transport, with 
aviation accounting for $40 \%$ of tourism's overall carbon footprint, followed by car transport (32\%) and accommodation (21\%) (UNWTO-UNEP-WMO, 2008). Cruise ships provide an estimated 19.2 $\mathrm{Mt} \mathrm{CO}_{2}$, and account for around $1.5 \%$ of global tourism emissions (Eijgelaar, Thaper \& Peeters, 2010; see also WEF, 2009). The frequently quoted assessments of the tourism sector's contribution to climate change conducted by the UNWTO-UNEP-WMO (2008) and WEF (2009) do not include the impact of non- $\mathrm{CO}_{2} \mathrm{GHGs}$. A more accurate assessment of tourism's contribution to climate change can be made on the basis of radiative forcing (RF). With RF considered (a particularly important uncertainty of aviation emissions), it was estimated that tourism contributed $5.2-12.5 \%$ of all anthropogenic forcing in 2005, with a best estimate of approximately 8\% (Scott, Peeters \& Gössling, 2010; Gössling, Scott \& Hall, 2013). Any assessment of tourism's "significance" would also have to consider that this is the effect of the activities of a minor proportion of the global population, with only an estimated $2-3 \%$ of the world's population participating in international air travel in a given year (Peeters et al., 2007). Given that the rate of growth in tourism is increasing at a higher rate than efficiency gains, the absolute contribution of tourism to climate change is therefore increasing and, unless there are changes in the nature of tourism consumption (which does not necessitate a radical reduction in the number of tourist trips), the emissions from tourism will continue to grow in the foreseeable future (Dubois et al., 2011; Gössling, 2013; Gössling, Hall, Peeters \& Scott, 2010; Gössling, Scott \& Hall, 2013; Owens, Lee \& Lim, 2010; Peeters \& Dubois, 2010; Peeters \& Landré, 2012). For this reason the World Travel and Tourism Council (WTTC) (2009) established 'aspirational' $\mathrm{CO}_{2}$ reduction targets, which were subsequently endorsed by the UNWTO and other tourism organizations. Like every industry association, the WTTC does not issue such pronouncements without diligent consideration of the scientific evidence of climate change, the contribution of the tourism sector to anthropogenic climate change (ACC) and the implications of ACC for the tourism sector (Scott, Hall, Gössling, 2012).

Shani and Arad (2014, p.84) end their work with a distinction between the "worthy cases" which the tourism industry "ought to address" and the worthless (according to their perspective) "fight" against ACC that, they claim, is "a phenomenon not yet well understood". On their list of "worthy cases" they mention issues such as "Preservation of natural assets and culture ... prevention of environmental degradation caused by tourism activities, wildlife conservation and protection of endangered species, as well as empowerment and promotion of the wellbeing of local communities" (Shani \& Arad, 2014, p.84). Shani and Arad (2014) argue for the moral obligation of environmental sustainability being part of the tourism industry's agenda but not climate change. This artificial distinction reveals an inadequate knowledge of climate change and sustainability (Buckley, 2012; Hall, 2011), as well as an inherent contradiction, because different forms of anthropogenic environmental change, including climate change, are embedded within each other, and cannot be easily separated. Yet, both climate and broader environmental change will negatively affect biodiversity and human wellbeing (IPCC 2013a, 2014a). The adaptive management steps needed for developing resilient and sustainable destinations therefore cannot ignore current and forecast climate change unless they are to be extremely partial and restricted in scope (Folke et al., 2002).

The question as to whether the tourism industry has a moral obligation to considerably diminish its greenhouse gas footprint and to educate tourists to alter their travel behavior is a question of values (Hall et al., 2014a). More than 20 years ago, Stern, Dietz and Kalof (1993) showed that at least three value orientations underpin environmental attitudes and 
behavior, with one of those, a social-altruistic value orientation, linked to concern for the welfare of other human beings, and another a biospheric orientation, linked to concern over non-human species or the biosphere. The third is egoism or self-interest. A pure orientation towards egoism would suggest that any environmental concern would be based only on selfinterest, where 'an individual would favor protecting the environment when and only when doing so would outweigh the expected costs' (Stern et al., 1993, p.326). While this study showed that most people reflect some combination of the three, if Shani and Arad's (2014a, b) value orientation leans towards self-interest in the context of climate change, as indicated by their support for Ayn Rand's 'philosophies', then this stance should be recognized overtly in their work, and account taken of how that affects their recommendations to the tourism industry and the academy (see also Hall et al., 2014b).

With some possible exceptions in the area of ecotourism, the tourism industry overall is unlikely to identify with a stance that openly eschews concern for other beings and/or the biosphere ahead of immediate economic concerns. Nevertheless, there are consumer, political and economic pressures for the tourism industry to act as good corporate citizens, including with respect to the environment, while in some jurisdictions there may even be legal requirements to reduce emissions and environmental impacts. As described above, the tourism industry is a significant contributor to climate change. The present industry focus with respect to emissions reduction and energy consumption is to become more efficient. However, there are clear limits to such gains and given rates of forecast growth in tourism it is likely that other measures, such as carbon caps, taxes and trading schemes as well as greater encouragement for offsetting and behavioral change will have to be applied if tourism is to meet its emissions targets (Cohen, Higham, Peeters \& Gössling, 2014; Dubois et al., 2011; Gössling et al., 2013; Hall, 2014; Peeters \& Dubois, 2010).

Does human-induced climate change pose a threat to the attractiveness and sustainability of tourism destinations? (Shani \& Arad, 2014a, p.82)

On the basis of a range of evidence, human-induced climate change does pose a threat to the attractiveness and sustainability of tourism destinations (Scott, Hall, \& Gössling 2012). This will occur over various time scales depending on the specific factors e.g. sea level rise, snow loss, ocean acidification, coral bleaching, species loss, that will affect the relative attractiveness of destinations (Scott, Hall \& Gössling, 2012). Importantly, the impacts of climate change on tourism cannot be treated in isolation with respect to a single destination, but need to be seen in terms of the relative effects of climate change in all destinations that a potential tourist might visit (Hamilton et al. 2005; Scott, Hall \& Gössling, 2012; TervoKankare, Hall \& Saarinen, 2013). However, the impact of climate change on tourism also needs to be understood in relation to all elements of the tourism system rather than destinations alone, as its effects in tourism generating regions will also affect economic wellbeing in those countries and therefore propensities to travel. The tourism literature acknowledges that while some destinations and generating regions may benefit from climate change in the short-term over the longer-term the systemic effects of climate change will have significant consequences for tourism in all countries (Scott, Gössling \& Hall, 2012). This may be especially so for the least developed countries that are likely to be among the most affected by climate change and which increasingly also have a strong focus on tourism as a development mechanism (Hall, Scott \& Gössling, 2013).

\section{Conclusions}


Reviewing the work of Shani and Arad (2014a, b) and others like them is an exercise in agnotologyiv. Although no single peer-reviewed publication on climate change, or any other scientific issue, should be accepted without due scrutiny, the existence of a scientific consensus, especially one as overwhelming as exists for human-induced climate change, raises the level of confidence that the overall findings of that consensus are correct (Bedford \& Cook, 2013; Cook et al., 2014a). In examining the scientific consensus on AGW in the peerreviewed scientific literature, Cook et al. (2013) examined 11,944 climate abstracts from 1991-2011 matching the topics 'global climate change' or 'global warming'. They found that $66.4 \%$ of abstracts expressed no position on AGW, 32.6\% endorsed AGW, $0.7 \%$ rejected AGW and $0.3 \%$ were uncertain about the cause of global warming. Among abstracts expressing a position on AGW, 97.1\% endorsed the consensus position that humans are the primary cause of contemporary global warming. Cook et al's (2013) analysis, among others (e.g. Anderegg et al., 2010; Doran \& Zimmerman, 2009), indicates that the number of papers rejecting the consensus on AGW is a very small proportion of published peer-reviewed research. Even Tol (2014) in his examination of Cook et al. (2013) states, "There is no doubt in my mind that the literature on climate change overwhelmingly supports the hypothesis that climate change is caused by humans. I have very little reason to doubt that the consensus is indeed correct". Cook et al's (2014a, b) responses to Tol (2014) indicated that claims of a slightly lower consensus by Tol result from a basic calculation error and that running the same tests using appropriate consensus statistics shows no evidence of inconsistency and confirm that the consensus is robust at $97 \pm 1 \%$. It is not sufficient, as Shani and Arad (2014a) do, to rely on substantially criticized outlier studies and "anecdotes" (Shani and Arad, 2014b) to dispute climate change science.

There is nevertheless a very clear difference between a scientific and a public consensus. Public perception and understanding of anthropogenic climate change is, at times, confused and there remains a varying proportion of the population of some countries that do not believe ACC is occurring. There are a number of reasons for this. First, media reporting on climate change as a 'divided' issue, purporting an understanding that scientists are divided (Boykoff \& Boykoff, 2007) and/or dishonest (Maibach et al., 2012) over ACC. Anderegg (2010) consequently suggests that scientists need to better communicate their research to audiences. Second, natural hazard research has demonstrated that many people, including in the tourism industry, do not believe that a hazard exists until an event affects them that changes their mind (Saarinen \& Tervo, 2010; Scott, Hall \& Gössling, 2012). There is also evidence that personal experiences can also affect political attitudes and behaviors with respect to climate change (Egan \& Mullin, 2012). Third, there is an extensive campaign by some organizations to discredit climate change science that has had a significant effect on the representation of the scientific consensus on climate change in a number of countries (Manne, 2012; Brulle, 2014) as well as capacities to undertake climate change research (Gleick, 2010). For example, Jacques, Dunlap, and Freeman (2008) and Brulle (2014) highlight the role of conservative think tanks with respect to organized environmental skepticism. Such activities also now appear to be increasingly entering the academic publishing arena. Finally, no matter what arguments are presented there will always be 'scientific fundamentalists' who will not accept the evidence if it is incongruent with their belief system (Kahan et al., 2012). As Dunlap (2013, p.693) observed, "there is little doubt that many individuals actively involved in the denial campaign are not skeptical of climate science but are in full denial, and no amount of evidence will convince them of the reality of AGW." It is just unfortunate that sometimes such fundamentalism and misrepresentation of a 
subject is given a platform in what are meant to be quality, peer-reviewed, journals as scientific papers rather than as commentaries or personal viewpoints, if at all (Hall et al., $2014 b)$. As Tol (2008, p.37) forthrightly noted, 'Denying that there is a problem [of climate change] is just dumb.'

Even with a scientific consensus on the reality of climate change this does not mean that there is no critical debate. There is substantial debate over many aspects of climate change science, not only with respect to levels of confidence and uncertainty, but also the paradigms and frameworks within which it is understood as a problem to be managed and solved (Beck et al. 2013; Hall, 2011, 2013; Hulme, 2011). These debates also occur within research on climate change and tourism (Scott, 2011) as well as its broader relationship to sustainable tourism and mobility. This has therefore meant, both within climate change research in general and tourism specifically, that there is substantial contestation over issues of adaptation, mitigation, vulnerability and resilience. Such areas are where debate should be focused especially in the light of issues of policy learning and flexibility, climate change governance, the role of the market, consumer behavior, opportunity costs and development.

Finally, we acknowledge that understanding what constitutes 'development', 'progress', 'sustainability' and 'morality' with respect to climate change action remains a contested area. For a complex problem with such a global scope and far reaching consequences this is understandable. The Davos Conference on Climate Change and Tourism identified "climate change as one of the greatest challenges to sustainable tourism in the $21^{\text {st }}$ century" (UNWTO-UNEP-WMO, 2008) and that same year tourism was identified as one of five sectors in the 'danger zone' of climate change in a global business analysis by KPMG (2008). At a time when governments and business around the world are increasingly responding to the challenges of climate change (e.g. Carbon Disclosure Project, 2013), Shani and Arad (2014a, b) would have the tourism sector fall yet further behind (Hall et al. 2014a, b).

There is no shortage of recognition within the tourism industry that climate change is real. The issue now is how to best respond over the short and long-term. Research on climate change and tourism has identified a number of short and long-term initiatives that can be undertaken to reduce the tourism industry's emissions (Becken \& Hay, 2012; Scott et al., 2012). Significantly, these rely on more than just increases in efficiency to also identify potential changes in behavior (Cohen et al., 2014; Hall, 2014), all without necessarily reducing the amount of tourist travel as measured by the number of trips (Peeters \& Dubois, 2010; Gössling, Scott \& Hall, 2015). The critical difference lies in selecting long-term options, potentially revolving around issues of governance and as to whether an industry selfregulatory approach will achieve required emissions reduction faster than appropriate government interventions, especially with respect to the creation of inclusive carbon markets that set limits on the total amount of carbon that can be emitted (Gössling, Scott \& Hall, 2013). Furthermore, in such a context it is also apparent that researchers on climate change and tourism may also need to do more to effectively communicate options to tourism business, policy-makers and non-government organizations, especially in the light of the potential confusion created by those that deny climate change and the urgency to reduce emissions and improve energy and environmental performance.

However, taking action to achieve limits in global warming to $2^{\circ} \mathrm{C}$ raises not just economic and technical challenges, but also profound questions of ethics and values, including the 
responsibility we bear towards future generations, and attitudes to climate change risk, including who will be most affected. But what is not understandable is the masquerading of what is presented as skepticism in science in academic journals. Liberal science requires debate but it must be scientifically informed. Concern by tourism scholars and some policy makers over the impacts of anthropogenic climate change is neither a fashionable belief nor does it set out to be alarmist. Rather than being grounded in fashion or dogma, concerns over the effects of climate change on tourism and tourism's contribution to climate change are firmly grounded in rigorous scientific evidence, discussion, debate and findings in which alternative hypotheses for climate variability are rejected simply because they do not fit the facts. We can only wish that the arguments of so-called environmental and rational skeptics could be similarly framed; yet, as shown in this response to climate change denial in tourism, they rarely are.

\section{Acknowledgements}

The authors would like to acknowledge the valuable comments of the anonymous referees as well as the support of the following with respect to a separate rejoinder to Shani and Arad: Carlo Aall; Bruno Abegg; Jorge Araña; Stewart Barr; Susanne Becken; Ralf Buckley; Peter Burns; Tim Coles; Jackie Dawson; Rouven Doran; Ghislain Dubois; David Timothy Duval; David Fennell; Alison Gill; Martin Gren; Werner Gronau; Jo Guiver; Debbie Hopkins; Edward H. Huijbens; Ko Koens; Machiel Lamers; Christopher Lemieux; Alan Lew; Patrick Long; Frans Melissen; Jeroen Nawijn; Sarah Nicholls; Jan-Henrik Nilsson; Robin Nunkoo; Alan Pomering; Arianne Reis; Dirk Reiser; Robert Richardson; Christian Rogerson; Jarkko Saarinen; Anna Dóra Sæpórsdóttir; Robert Steiger; Paul Upham; Sander van der Linden; Gustav Visser; Geoffrey Wall; David Weaver

\section{References}

Anderegg, W.R. (2010). The ivory lighthouse: communicating climate change more effectively. Climatic Change, 101, 655-662.

Anderegg, W.R., Prall, J.W., Harold, J., \& Schneider, S.H. (2010). Expert credibility in climate change. Proceedings of the National Academy of Sciences, 107(27), 12107-12109.

Archer, D., \& Pierrehumbert, R. (eds.) (2011). The warming papers. The scientific foundation for the climate change forecast. Chichester: Wiley-Blackwell.

Balmaseda, M.A., Trenberth, K.E., \& Källén, E. (2013). Distinctive climate signals in reanalysis of global ocean heat content. Geophysical Research Letters, 40(9), 1754-1759.

Barnett, V. (2004). Environmental Statistics. Chichester: John Wiley \& Sons.

Beck, S., Borie, M., Chilvers, J., Esguerra, A., Heubach, K., Hulme, M., Lidskog, R., Lövbrand, E., Marquard, E., Miller, C., Nadim, T., Neßhöver, C., Settele, J., Turnhout, E., Vasileiadou, E., \& Görg, C. (2014). Towards a reflexive turn in the governance of global environmental expertise. The cases of the IPCC and the IPBES. GAIA - Ecological Perspectives for Science and Society, 23(2), 80-87.

Becken, S., \& Hay, J.E. (2012). Climate change and tourism: From policy to practice. Abingdon: Earthscan.

Bedford, D., \& Cook, J. (2013). Agnotology, scientific consensus, and the teaching and learning of climate change: A response to Legates, Soon and Briggs. Science \& Education, 22(8), 2019-2030. 
Bigano, A., Hamilton, J.M., Maddison, D.J., \& Tol, R.S.J. (2006). Predicting tourism flows under climate change. An editorial comment on Gössling and Hall (2006), Climatic Change, 79, 175-180.

Bond, G., Kromer, B., Beer, J., Muscheler, R., Evens, M. N., Showers, W., Hoffmann, S., LottiBond, R-L., Hjajdas, I., \& Bonani, G. (2001). Persistent solar influence on North Atlantic climate during the Holocene. Science, 294(5549), 2130-2136.

Boykoff, T., \& Boykoff, J. (2007). Climate change and journalistic norms: A case-study of US mass-media coverage. Geoforum, 28(6), 1190-1204.

Bracken, C.J., \& Oughton, E.A. (2006). "What do you mean?" The importance of language in developing interdisciplinary research. Transactions of the Institute of British Geographers, 31, 371-382.

Brulle, R.J. (2014). Institutionalizing delay: Foundation founding and the creation of US climate change counter-movement organizations. Climatic Change, 122, 681-694.

Brysse, K., Oreskes, N., O’Reilly, J., \& Oppenheimer, M. (2013). Climate change prediction: Erring on the side of least drama?. Global Environmental Change, 23(1), 327-337.

Buckley, R. (2012). Sustainable tourism: Research and reality. Annals of Tourism Research, 39(2), 528-546.

Carbon Disclosure Project (2013). Global 500 Climate Change Report 2013. London: CFP.

Cohen, S., Higham, J.E., Peeters, P., \& Gössling, S. (Eds.) (2014). Understanding and Governing Sustainable Tourism Mobility: Psychological and Behavioural Approaches, Abingdon: Routledge.

Cook, J., Nuccitelli, D., Green, S.A., Richardson, M., Winkler, B., Painting, R., Way, R., Jacobs, P., \& Skuce, A. (2013). Quantifying the consensus on anthropogenic global warming in the scientific literature. Environmental Research Letters, 8(2), 024024.

Cook, J., Nuccitelli, D., Skuce, A., Jacobs, P., Painting, R., Honeycutt, R., Green, S.A., Lewandowsky, S., Richardson, M., \& Way, R.G. (2014). Reply to 'Quantifying the consensus on anthropogenic global warming in the scientific literature: A re-analysis'. Energy Policy, in press corrected proof, DOI: 10.1016/j.enpol.2014.06.002

Cook, J., Nuccitelli, D., Skuce, A., Way, R., Jacobs, P., Painting, R., Honeycutt, R., Green, S.A., Lewandowsky, S., \& Coulter, A. (2014) 24 Critical Errors in Tol (2014). Reaffirming the 97\% consensus on anthropogenic global warming. Brisbane: Global Change Institute. Available online: http://www.gci.uq.edu.au/images/uploads/news/24CriticalErrorsinTol2014.pdf

Collins, M., An, S-I, Cai, W., Ganachaud, A., Guilyardi, E., Jin, F-F., Jochum, M., Lengaigne, M., Power, S., Timmermann, A., Vecchi, G., \& Wittenberg, A. (2010). The impact of global warming on the tropical Pacific Ocean and El Niño. Nature Geoscience, 3, 391-397.

Committee of Science and Technology (2010). A rational discussion of climate change: The science, the evidence, the response. Hearing before the Subcommittee on Energy and Environment Committee on Science and Technology, House of Representatives One Hundred Eleventh Congress Second Session, November 17, 2010. Washington DC: US Government Printing Office.

Curry, J. (2011). Reasoning about climate uncertainty. Climatic Change, 108, 723-732.

Czech, B. (2008). Prospects for reconciling the conflict between economic growth and biodiversity conservation with technological progress. Conservation Biology, 22: 13891398.

Daily, G. (ed.) (1997). Nature's Services. Washington DC: Island Press.

Dasgupta, S., Laplante, B., Wang, H., \& Wheeler, D. (2002). Confronting the environmental Kuznets curve. Journal of Economic Perspectives, 16(1): 147-168. 
Demeritt, D. (2001a). The construction of global warming and the politics of science. Annals of the Association of American Geographers, 91(2), 307-337.

Demeritt, D. (2001b). Science and the understanding of science: A reply to Schneider. Annals of the Association of American Geographers, 91(2), 345-348.

Demeritt, D. (2006). Science studies, climate change and the prospects for constructivist critique. Economy and Society, 35(3), 453-479.

Demeritt, D., \& Rothman, D. (1999). Figuring the costs of climate change: An assessment and critique. Environment and Planning A, 31(3), 389-408.

Dietz, S., \& Adger, W.N. (2003). Economic growth, biodiversity loss and conservation effort. Journal of Environmental Management, 68: 23-35.

Doran, P.T., \& Zimmerman, M.K. (2009). Examining the scientific consensus on climate change. Eos, Transactions American Geophysical Union, 90(3), 22-23.

Dubois, G., Peeters, P., Ceron, J-P., \& Gössling, S. (2011). The future tourism mobility of the world population: Emission growth versus climate policy. Transportation Research Part A: Policy and Practice, 45(10), 1031-1042.

Dunlap, R.E. (2013). Climate change skepticism and denial: An introduction. American Behavioral Scientist, 57(6), 691-698.

Egan, P.J., \& Mullin, M. (2012). Turning personal experience into political attitudes: The effect of local weather on Americans' perceptions about global warming. Journal of Politics, 74(3), 796-809.

Eijgelaar, E., Thaper, C., \& Peeters, P. (2010). Antarctic cruise tourism: the paradoxes of ambAradorship, "last chance tourism" and greenhouse gas emissions. Journal of Sustainable Tourism, 18, 337-354.

England, M.H., McGregor, S., Spence, P., Meehl, G., Timmermann, A., Cai, W., Sen Gupta, A., McPhaden, M.J., Purich, A., \& Santoso, A. (2014). Recent intensification of wind-driven circulation in the Pacific and the ongoing warming hiatus. Nature Climate Change, 4 , 222-227.

Esbjörn-Hargens, S. (2010). An ontology of climate change. Journal of Integral Theory \& Practice, 5(1), 143-174.

Esper, J., Büntgen, U., Timonen, M., \& Frank, D.C. (2012). Variability and extremes of northern Scandinavian summer temperatures over the past two millennia. Global and Planetary Change, 88-89, 1-9.

Folke, C., Carpenter, S., Elmqvist, T., Gunderson, L., Holling, C.S., \& Walker, B. (2002). Resilience and sustainable development: building adaptive capacity in a world of transformations. AMBIO: A journal of the human environment, 31(5), 437-440.

Ford, J.D., Bolton, K., Shirley, J., Pearce, T., Tremblay, M., \& Westlake, M. (2012). Mapping human dimensions of climate change research in the Canadian Arctic. Ambio, 41(8), 808-822.

Ford, J.D., Knight, M., \& Pearce, T. (2013). Assessing the 'usability' of climate change research for decision-making: A case study of the Canadian International Polar Year. Global Environmental Change, 23(5), 1317-1326.

Friel, H. (2010). The Lomborg deception: Setting the record straight about global warming. New Haven: Yale University Press.

Gelbspan, R. (1997). The heat is on: The high stakes battle over Earth's threatened climate. Reading, MA: Addison-Wesley.

Gleckler, P.J., Taylor, K.E., \& Doutriaux, C. (2008). Performance metrics for climate models. Journal of Geophysical Research: Atmospheres (1984-2012), 113(D6).

Gleick, P.H. et al. (2010). Letters: Climate change and the integrity of science. Science, 328(5979), 689-690. 
Guo, Z., Zhang, L., \& Li, Y. (2010). Increased dependence of humans on ecosystem services and biodiversity. PLoS One, 5(10), e13113.

Gössling, S. (2010). Carbon management in tourism: Mitigating the impacts on climate change. London: Routledge.

Gössling, S. (2013). National emissions from tourism: an overlooked policy challenge? Energy Policy, 59, 433-442.

Gössling, S., \& Hall, C.M. (2006a). Uncertainties in predicting tourist flows under scenarios of climate change. Climatic Change, 79(3-4), 163-73.

Gössling, S., \& Hall, C.M. (2006b). Uncertainties in predicting travel flows: common ground and research needs. A reply to Tol et al. Climatic Change, 79(3-4), 181-3.

Gössling, S., Hall, C.M., Ekström, F., Brudvik Engeset, A., \& Aall, C. (2012). Transition management: a tool for implementing sustainable tourism scenarios? Journal of Sustainable Tourism, 20(6), 899-916.

Gössling, S., Hall, C.M., Lane, B., \& Weaver, D. (2008). The Helsingborg statement on sustainable tourism. Journal of Sustainable Tourism, 16(1), 122-124.

Gössling, S., Hall, C.M., Peeters, P., \& Scott, D. (2010). The future of tourism: A climate change mitigation perspective. Tourism Recreation Research, 35(2), 119-130.

Gössling, S., Scott, D., \& Hall, C.M. (2013). Challenges of tourism in a low-carbon economy, WIRES Climate Change, 4(6), 525-538.

Gössling, S., Scott, D. \& Hall, C.M. (2015). Inter-market variability in $\mathrm{CO}_{2}$ emission-intensities in tourism: Implications for destination marketing and carbon management. Tourism Management, 46, 203-212.

Hall, C.M. (2009). Degrowing tourism: Décroissance, sustainable consumption and steadystate tourism. Anatolia, 20(1), 46-61.

Hall, C.M. (2010). Changing paradigms and global change: From sustainable to steady-state tourism. Tourism Recreation Research, 35(2), 131-145.

Hall, C.M. (2011). Policy learning and policy failure in sustainable tourism governance: From first and second to third order change? Journal of Sustainable Tourism, 19(4-5), 649671.

Hall, C.M. (2013). Framing behavioural approaches to understanding and governing sustainable tourism consumption: Beyond neoliberalism, 'nudging' and 'green growth'? Journal of Sustainable Tourism, 21(7), 1091-1109.

Hall, C.M. (2014). Tourism and social marketing. Abingdon: Routledge.

Hall, C.M., Scott, D., \& Gössling, S. (2013). The primacy of climate change for sustainable international tourism, Sustainable Development, 21(2), 112-121.

Hall, C.M., Amelung, B., Cohen, S., Eijgelaar, E., Gössling, S., Higham, J., Leemans, R., Peeters, P., Ram, Y., Scott, D., Aall, C., Abegg, B., Araña, J.E., Barr, S., Becken, S., Buckley, R., Burns, P., Coles, T., Dawson, J., Doran, R., Dubois, G., Duval, D., Fennell, D., Gill, A., Gren, M., Gronau, W., Guiver, J., Hopkins, D., Huijbens, E.H., Koens, K., Lamers, M., Lemieux, C., Lew, A., Long, P., Koens, K., Melissen, F.W., Nawijn, J., Nicholls, S., Nilsson, J-H., Pomering, A., Reis, A.C., Reiser, D., Richardson, R.B., Rogerson, C.M., Saarinen, J., Sæpórsdóttir, A.D., Steiger, R., Upham, P., van der Linden, S., Visser, G., Wall, G., Weaver, D. (2014a). No time for smokescreen skepticism: A rejoinder to Shani and Arad. Tourism Management, accepted. Available online:

https://www.academia.edu/6893990/No_time_for_smokescreen_skepticism_A_rejoin der_to_Shani_and_Arad

Hall, C.M. et al. (2014b). Denying bogus skepticism in climate change and tourism research. Tourism Management, submitted. Available online: 
https://www.academia.edu/7662616/Denying_Bogus_Skepticism_in_Climate_Change _and_Tourism_Research.

Hoffman, A.J. (2011). Talking past each other? Cultural framing of skeptical and convinced logics in the climate change debate. Organization \& Environment, 24(1), 3-33.

Hoggan, J. (2009). Climate cover-up: The crusade to deny global warming. Vancouver: Greystone Books.

Hulme, M. (2009). Why we disagree about climate change: understanding controversy, inaction and opportunity. Cambridge: Cambridge University Press.

Hulme, M. (2011). Meet the humanities. Nature Climate Change, 1(4), 177-179.

IPCC (2013a). Climate change 2013: The physical science basis. Contribution of Working Group I to the Fifth Assessment Report of the Intergovernmental Panel on Climate Change [Stocker, T.F., D. Qin, G.-K. Plattner, M. Tignor, S.K. Allen, J. Boschung, A. Nauels, Y. Xia, V. Bex and P.M. Midgley (eds.)]. Cambridge: Cambridge University Press.

IPCC (2013b). Summary for Policymakers. In Climate change 2013: The physical science basis. Contribution of Working Group I to the Fifth Assessment Report of the Intergovernmental Panel on Climate Change [Stocker, T.F., D. Qin, G.-K. Plattner, M. Tignor, S.K. Allen, J. Boschung, A. Nauels, Y. Xia, V. Bex \& P.M. Midgley (eds.)]. Cambridge: Cambridge University Press.

IPCC (2014a). Climate change 2014: Impacts, adaptation, and vulnerability. Working Group II. Approved final draft. 30 March 2014. Available online http://www.ipccwg2.gov/AR5/ Accessed 1/4/14

IPCC (2014b). Summary for Policymakers. Climate change 2014: Mitigation of climate change. Working Group III. Approved final draft. Available online http://www.ipccwg2.gov/AR5/ Accessed 13/4/14

Jacques, P., Dunlap, R., \& Freeman, M. (2008). The organization of denial: conservative think tanks and environmental skepticism. Environmental Politics, 17, 349-385.

Kahan, D., Peters, E., Wittlin, M., Slovic, P., Ouellette, L., Braman, D., \& Mandel, G. (2012). The polarizing impact of science literacy and numeracy on perceived climate change risks. Nature Climate Change, 2, 732-735.

Kaján, E., \& Saarinen, J. (2013). Tourism, climate change and adaptation: A review. Current Issues in Tourism, 16(2), 167-195.

Kijima, M., Nishide, K., \& Ohyama, A. (2010). Economic models for the environmental Kuznets curve: A survey. Journal of Economic Dynamics and Control, 34(7), 1187-1201.

KPMG (2008). Climate changes your business: KPMG's review of the business risks and economic impacts at sector level. Amstelveen, The Netherlands: KPMG.

Lockitch, K. (2009a). A critique of climate change science and policy. Environmental Issues, The Ayn Rand Institute, April 13 2009. Available online http://ari.aynrand.org/issues/science-and-industrialization/environmental-issues/ACritique-of-Climate-Change-Science-and-Policy Accessed 24/4/14

Lockitch, K. (2009b). Climate vulnerability and the indispensable value of industrial capitalism. Environmental Issues, The Ayn Rand Institute, September 2009. Available online http://ari.aynrand.org/issues/science-and-industrialization/environmentalissues/Climate-Vulnerability-and-the-Indispensable-Value-of-Industrial-Capitaism Accessed 24/4/14

Maibach, E., Myers, T., \& Leiserowitz, A. (2014). Climate scientists need to set the record straight: There is a scientific consensus that human-caused climate change is happening. Earth's Future, 2(5), 295-298. 
Maibach, E., Leiserowitz, A., Cobb, S., Shank, M., Cobb, K.M., \& Gulledge, J. (2012). The legacy of climategate: undermining or revitalizing climate science and policy? Wiley Interdisciplinary Reviews: Climate Change, 3(3), 289-295.

Mann, M.E. (2012). The hockey stick and the climate wars: dispatches from the front lines. New York: Columbia University Press.

Mann, M.E., Steinman, B.A., \& Miller, S.K. (2014). On forced temperature changes, internal variability and the AMO. Geophysical Research Letters, DOI:10.1002/2014GL059233.

Manne, R. (2012). A dark victory: How vested interests defeated climate science. The Monthly, August, No. 81.

http://www.themonthly.com.au/issue/2012/august/1344299325/robert-manne/darkvictory

Marcott, S.A., Shakun, J.D., Clark, P.U. and Mix, A.C. (2013). A reconstruction of regional and global temperature for the past 11,300 years. Science, 339, 1198-1201.

Mervis, J. (2006). Judge Jones defines science-and why intelligent design isn't. Science, 311(6 Jan.), 34.

Millennium Assessment (2005). Ecosystems and human well-being. Washington, DC: Island Press.

Mills, J.H. and Waite, T.A. (2009) 'Economic prosperity, biodiversity conservation, and the environmental Kuznets curve', Ecological Economics, 68: 2087-2095.

Mozumder, P., Berrens, R.P., \& Bohara, A.K. (2006). Is there an environmental Kuznets curve for the risk of biodiversity loss? The Journal of Developing Areas, 39: 175-190.

Murphy, B.L. (2011). From interdisciplinary to inter-epistemological approaches: Confronting the challenges of integrated climate change research. The Canadian Geographer/Le Géographe canadien, 55(4), 490-509.

Nature Geoscience, (2014). Editorial. Hiatus in context. Nature Geoscience, 7, 157.

Neff, U., Burns, S.J., Mangini, A., Mudelsee, M., Fleitmann, D., \& Matter, A. (2001). Strong coherence between solar variability and the monsoon in Oman between 9 and $6 \mathrm{kyr}$ ago. Nature, 411, 290-293.

O'Brien, K. (2011). Responding to environmental change: A new age for human geography? Progress in Human Geography, 35(4), 542-549.

Oldfield, F., \& Steffen, W. (2014). Anthropogenic climate change and the nature of Earth system science. The Anthropocene Review, 1, 70-75

Oreskes, N. (2004). The scientific consensus on climate change. Science, 306(5702), 16861686.

Oreskes, N., \& Conway, E.M. (2010). Merchants of doubt. London, England: Bloomsbury.

Owens, B., Lee D.S., \& Lim, L. (2010). Flying into the future: aviation emissions scenarios to 2050. Environment Science \& Technology, 44, 2255-2260.

Pagani, M., Huber, M., Liu, Z., Bohaty, S., Henderiks, J., Sijp, W., Krishnan, S., \& Deconto, R.M. (2011). The role of Carbon Dioxide during the onset of Antarctic glaciation. Science, 334(6060), 1261-1264.

Peeters, P.M., \& Dubois, G. (2010). Tourism travel under climate change mitigation constraints. Journal of Transport Geography, 18, 447-457.

Peeters, P., Gössling, S. \& Becken, S. (2007). Innovation towards tourism sustainability: climate change and aviation. International Journal of Innovation and Sustainable Development, 1(3): 184-200.

Peeters, P., \& Landré, M. (2012). The emerging global tourism geography - an environmental sustainability perspective. Sustainability, 4(1), 2071-1050.

Petit, J.R., Jouze, J., Raynaud, D., Barkov, N.I., Barnola, J.M., Basile, I., Bender, M., Chappellaz, J., Davis, M., Delaygue, G., Delmotte, M., Kotlyakov, V.M., Legrand, M., 
Lipenkov, V.Y., Lorius, C., Pépin, L., Ritz, C., Saltzman, E., \& Stievenard, M. (1999). Climate and atmospheric history of the past 42,000 years from the Vostok ice core, Antarctica. Nature, 399, 429-436.

Refsgaard, J.C., Madsen, H., Andréassian, V., Arnbjerg-Nielsen, K., Davidson, T.A., Drews, M., Hamilton, D.P., Jeppesen, E., Kjellström, E., Olesen, J.E., Sonnenborg, T.O., Trolle, D., Willems, P., \& Christensen, J.H. (2014). A framework for testing the ability of models to project climate change and its impacts. Climatic Change, 122(1-2), 271-282.

Rosing, M.T., Bird, D.K., Sleep, N.H., \& Bjerrum, C.J. (2010). No climate paradox under the faint Sun. Nature, 464, 744-747.

Saarinen, J., \& Tervo, K. (2010). Sustainability and emerging awareness of a changing climate: the tourism industry's knowledge and perceptions of the future of naturebased winter tourism in Finland. In C.M. Hall \& J. Saarinen (Eds.), Tourism and change in polar regions: climate, environments and experiences (pp.147-164). Abingdon: Routledge.

Schmidt, G.A., Shindell, D.T., \& Tsigaridis, K. (2014). Reconciling warming trends. Nature Geoscience, 7(3), 158-160.

Schneider, S.H. (2001). A constructive deconstruction of deconstructionists: A response to Demeritt. Annals of the Association of American Geographers, 91(2), 338-344.

Science (2001). The science of climate change. Joint statement issued by the Australian Academy of Sciences, Royal Flemish Academy of Belgium for Sciences and the Arts, Brazilian Academy of Sciences, Royal Society of Canada, Caribbean Academy of Science, Chinese Academy of Science, French Academy of Sciences, German Academy of Natural Scientists Leopoldina, Indian National Science Academy, Indonesian Academy of Sciences, Royal Irish Academy, Accademia Nazionaledei Lincel (Italy), Academy of Sciences Malaysia, Academy Council of the Royal Society of New Zealand, Royal Swedish Academy of Sciences, Turkish Academy of Sciences, \& Royal Society (UK). Science, 292(5520), 18 May 2001, 1261.

Scott, D. (2011). Why sustainable tourism must address climate change. Journal of Sustainable Tourism, 19(1), 17-34.

Scott, D. Gössling, S., \& Hall, C.M. (2012). International tourism and climate change. Wiley Interdisciplinary Reviews: Climate Change, 3(3), 213-232.

Scott, D., Hall, C.M. \& Gössling, S. (2012). Tourism and Climate Change: Impacts, Adaptation and Mitigation, Abingdon: Routledge.

Scott, D., \& Matthews, L. (2011). Climate, Tourism \& Recreation: A Bibliography - 2010 Edition. Waterloo: Department of Geography and Environmental Management, University of Waterloo.

Scott, D., Peeters, P., \& Gössling, S. (2010). Can tourism deliver its "aspirational" greenhouse gas emission reduction targets?. Journal of Sustainable Tourism, 18(3), 393-408.

Shani, A., \& Arad, B. (2014). Climate change and tourism: Time for environmental skepticism. Tourism Management, 44, 82-85.

Shani, A., \& Arad, B. (2014b). There is always time for rational skepticism: Reply to Hall et al. Tourism Management, accepted manuscript.

Spencer, R.W., \& Braswell, W.D. (2014). The role of ENSO in global ocean temperature changes during 1955-2011 simulates with a 1D climate model. Asia- Pacific Journal of Atmospheric Science, 50(2), 229-237.

Stern, D.I. (2004). The rise and fall of the environmental Kuznets curve. World Development, 32: 1419-1439.

Stern, D.I. (2014). The Environmental Kuznets Curve: A Primer, CCEP Working Paper 1404. Canberra: Crawford School of Public Policy, The Australian National University. 
Stern, P.C., Dietz, T., \& Kalof, L. (1993). Value orientations, gender and environmental concern. Environment and Behavior, 25(3), 322-348.

Tervo-Kankare, K., Hall, C.M., \& Saarinen, J. (2013). Christmas tourists' perceptions of climate change in Rovaniemi, Finnish Lapland. Tourism Geographies, 15(2), 292-317.

Tol, R.S.J. (2008). Climate change: Regulating the unknown. In H. von Storrch, R.S.J. Tol, \& G. Flöser (eds.), Environmental crises (pp.37-51). Berlin: Springer.

Tol, R.S.J. (2013). Climate change: the economic impact of climate change in the twentieth and twenty-first centuries. In B. Lomborg (Ed.), How much have global problems cost the world? A Scorecard from 1900 to 2050 (pp.117-130). Cambridge: Cambridge University Press.

Tol, R.S.J. (2014). Quantifying the consensus on anthropogenic global warming in the literature: A re-analysis. Energy Policy, in press corrected proof, DOI: 10.1016/j.enpol.2014.04.045

Torras, M., \& Boyce, J.K. (1998). Income, inequality, and pollution: a reassessment of the environmental Kuznets curve. Ecological Economics, 25(2), 147-160.

Trenberth, K., \& Fasullo, J. (2013). An apparent hiatus in global warming? Earth's Future, $1(1), 19-32$.

Turnpenny, J., Jones, M., \& Lorenzoni, I. (2011). Where now for post-normal science? A critical review of its development, definitions, and uses. Science Technology Human Values, 36(3), 287-206.

United Nations World Tourism Organization, United Nations Environment Programme, and World Meterological Organization (UNWTO-UNEP-WMO) (2008). Climate change and tourism: responding to global challenges. Madrid: UNWTO.

Vahrenholt, F. (2012). Global warming: second thoughts of an environmentalist. The Telegraph. Available on

http://www.telegraph.co.uk/comment/9338939/Globalwarming-second-thoughts-ofan-environmentalist.html Accessed 10.4.14.

Weaver, D. (2011). Can sustainable tourism survive climate change?. Journal of Sustainable Tourism, 19(1), 5-15.

Weichselgartner, J., \& Kasperson, R. (2010). Barriers in the science-policy-practice interface: toward a knowledge-action-system in global environmental change research. Global Environmental Change, 20: 266-277.

Wilson, R. (2008). Against the evidence. Richard Wilson on the crucial difference between doubt and dogmatism. New Statesman, 18 September, www.newstatesman.com/ideas/2008/09/evidence-sceptic-hiv-bogus

Winowiecki, L., Smukler, S., Shirley, K., Remans, R., Peltier, G., Lothes, E., King, E., Comita, L., Baptista, S., \& Alkema, L. (2011). Tools for enhancing interdisciplinary communication. Science, Practice, and Policy, 7: 74-80.

World Commission for Environment and Development (WCED) (1987). Our common future. The Brundtland report. Oxford: Oxford University Press.

World Economic Forum (WEF) (2009). Towards a low carbon travel \& tourism sector. Davos: World Economic Forum.

World Meteorological Organization (WMO) (2013). The Global Climate 2001-2010. A decade of climate extremes. Summary report. WMO Report 1119, Geneva: WMO.

World Travel and Tourism Council (WTTC) (2009). Leading the challenge. London: WTTC.

Wyatt, M.G., \& Curry, J.A. (2013). Role for Eurasian Arctic shelf sea ice in a secularly varying hemispheric climate signal during the 20th century. Climate Dynamics, DOI:

10.1007/s00382-013-1950-2. 
Yeh, S.W., Kug, J.S., \& An, S.I. (2014). Recent progress on two types of El Niño: Observations, dynamics, and future changes. Asia-Pacific Journal of Atmospheric Sciences, 50(1), 6981.

' The period when human activities have, for the first time, had major impacts on the planet's ecosystems, including climates.

ii A Potemkin Village is a term used to describe a construction built to deceive. It is named after Prince Grigory Potemkin who supposedly erected fake villages along the Dnieper River in order to fool the entourage of Empress Catherine II of Russia during their visit to Crimea in 1787.

iii An op-ed is an opinion piece typically placed opposite the editorial page of a newspaper for maximum political effect.

iv Agnotology is the study of culturally induced ignorance or doubt, notably the publication of inaccurate / misleading scientific data 